\title{
High emergence of drug resistance after HAART interruption at delivery in a cohort of HIV+ pregnant women submitted to antiretroviral treatment to prevent mother-to-child transmission in Rio de Janeiro, Brazil
}

Jose Henrique Pilotto*1,2, Beatriz Grinsztejn ${ }^{1}$, Valdilea Veloso ${ }^{1}$, Jose Carlos Couto-Fernandez ${ }^{1}$, Adriana Rodrigues-Pedro ${ }^{1}$, Carlos Augusto Velasco-de-Castro1, Jorge Eurico Ribeiro' ${ }^{1}$, Ruth Khalili ${ }^{1}$, Sandra Muri ${ }^{1}$, Ronaldo Ismerio ${ }^{1}$, Judith Courrier ${ }^{3}$ and Mariza G Morgado ${ }^{1}$

Address: ${ }^{1}$ Fundação Oswaldo Cruz, Rio de Janeiro, RJ, Brazil, ${ }^{2}$ Hospital Geral de Nova Iguaçu, Nova Iguaçu, RJ, Brazil and ${ }^{3}$ Univ. of California, Los Angeles, CA, USA

* Corresponding author

from Fifth Dominique Dormont International Conference. Mother-to-child transmitted viral diseases: from transmission to children care Paris, France. 26-28 March 2009

Published: 22 July 2009

Retrovirology 2009, 6(Suppl I):OI4 doi:10.II86/I742-4690-6-SI-OI4

This abstract is available from: http://www.retrovirology.com/content/6/SI/OI4

(C) 2009 Pilotto et al; licensee BioMed Central Ltd.

\section{Background}

Brazilian guidelines stipulate that HIV+ pregnant women initiating HAART for PMTCT, who do not otherwise need ARV for their own health, discontinue antiretrovirals after delivery. However, it is unknown how frequent drug resistance is with this strategy.

\section{Objectives}

to evaluate HIV-1 primary resistance at baseline visit, the impact of antiretroviral discontinuation, following delivery for the emergence of genotypic resistance, HIV-1 subtype, HIV-1 recent Infection using the Calypte BED Incidence EIA, and the rates of HIV-1 vertical transmission in this population of HIV-1 pregnant women.

\section{Methods}

Since January 2005, an HIV+ pregnant women cohort has been established at Hospital Geral de Nova Iguaçu. HAART for PMTCT was used according to the Brazilian Guidelines. Clinical/lab evaluations (CD4, HIV-RNA and genotyping were performed at baseline, 6-8 weeks after HAART, delivery and postpartum [15 days, 1 month and 6 months]).

\section{Results}

139 women/babies have been enrolled and followed. Median age is 25.3 years; $69.8 \%$ women are non-white, median gestational age at prenatal care initiation is 24 weeks. Median CD4 cell count at baseline is 518 cells/ mm3 and HIV-1 VL 7.800 copies/mL. A NNRTI and PI based regimen was prescribed for $22.3 \%$ and $77.7 \%$ of the women, respectively. The median time on ART was 84 days; $76 \%$ had HIV-1 RNA $<400$ copies/ml at delivery. The prevalence of HIV primary drug resistant was $11.3 \%$ at baseline visit, and $13.8 \%$ of the women developed new mutations after ART interruption at delivery. HIV-1 recent infection was detected in $13.9 \%$ pregnant women at baseline visit. In the multivariate analysis, HIV-1 primary resistance was independently associated with the development of new resistance mutations at delivery/post-partum. Pregnant women with detectable HIV-1 RNA at delivery had a RR of detection of mutations at delivery/ post-partum 3.5 times the one for women with undetectable HIV-1 RNA at delivery. The length of time of HAART use was independently associated with the incidence of resistance after ART initiation for PMTCT. 


\section{Conclusion}

High Prevalence of HIV-1 primary resistance at baseline visit; $13.8 \%$ of the women developed new mutations after ART interruption after delivery. HIV-1 recent infection was detected in $13.9 \%$ pregnant women at baseline visit. HIV subtype B was the most prevalent. There was no HIV-1 vertical transmission.

Publish with Bio Med Central and every scientist can read your work free of charge

"BioMed Central will be the most significant development for disseminating the results of biomedical research in our lifetime. " Sir Paul Nurse, Cancer Research UK

Your research papers will be:

- available free of charge to the entire biomedical community

- peer reviewed and published immediately upon acceptance

- cited in PubMed and archived on PubMed Central

- yours - you keep the copyright 